\title{
TRENDS IN THE PREVALENCE OF VENEREAL DISEASES IN ENGLAND AND WALES*
}

\author{
BY \\ R. R. WILLCOX \\ Consultant Venereologist, St. Mary's Hospital, Paddington, and King Edward VII Hospital, Windsor; \\ Member of W.H.O. Expert Panel on Venereal Infections and Treponematoses
}

The venereal diseases are and have been of particular interest to the epidemiologist throughout recorded history. We learn from Leviticus $x v$, that, in Biblical times, doubtless in response to the best epidemiological advice of the day, sufferers from gonorrhoea were excluded from the tabernacle; not only was the patient himself considered unclean but also his bed, garments, and anything he might have sat upon-including his saddle, and also his eating and drinking vessels. The infected patient remained an outcast from the camp for 7 days after the cessation of the discharge, and could then make atonement by disinfection and by the offering in the tabernacle of two turtle doves or two young pigeons.

Whether syphilis existed in those times is more controversial, but the drastic preventive medicine ordered by Moses, entailing the slaughter of all the Midianite women "that hath known man by lying with him" (Numbers xxxi) was founded upon an epidemiological study of the plague of Moab which some believe to have been an example of this serious disease (Willcox, 1949).

In modern times the venereal diseases still offer an opportunity for epidemiological studies, as most countries can supply at least crude statistics of the numbers of cases treated in hospitals and clinics. Only when a national health service has reached the stage of being adequate for the potential demand, do such statistics become of value in assessing trends of prevalence.

The present paper is concerned with trends in the prevalence of the venereal diseases in the clinics of England and Wales (which are officially considered separately from Scotland) during the past 35 years.

The statistics from these clinics, published annually in the "Report of the Chief Medical Officer to the Ministry of Health", are available for each year since 1925; greater detail has been supplied since 1931 and again since 1951. The author has drawn freely on these figures, and also on those published by the British Cooperative Clinical Group (1956, 1960a, b, 1962). It must, however, be

* Paper read at Section of Epidemiology and Preventive Medicine, Royal Society of Medicine, London, November, 1961. emphasized that these take no account of patients treated by private practitioners; surveys have shown that these may not be as numerous as is sometimes thought (British Cooperative Clinical Group, 1959).

Relative Importance of Various Venereal Diseases

This is shown for the 1959 figures in Table I and Fig. 1.

TABLE I

RELATIVE IMPORTANCE OF VARIOUS VENEREAL INCIDENCE OF NEW CASES IN 1959, BY SEX

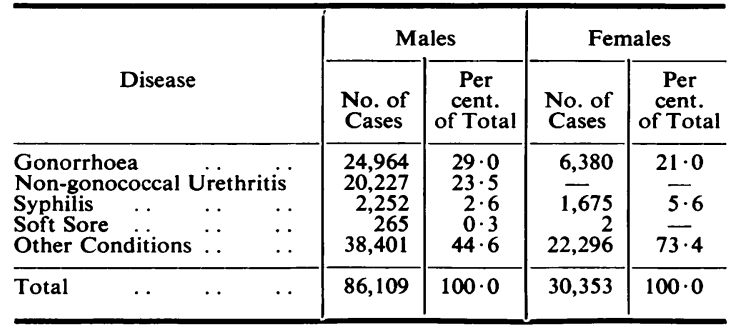

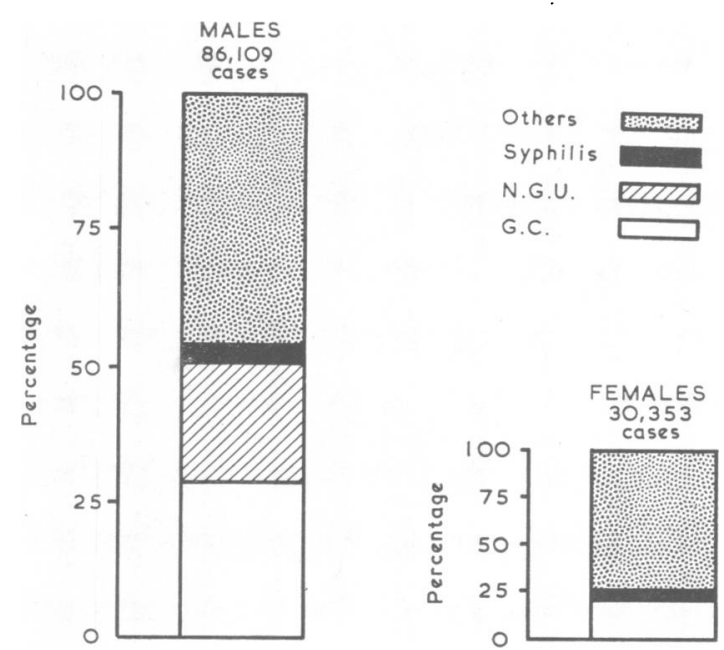

FIG. 1.-Relative numerical importance of the venereal diseases in England and Wales, by sex, 1959.

(Soft sore, lymphogranuloma venereum, and granuloma inguinale too few to be recorded.) 
Nearly three times the number of new cases were seen in males than in females: and of gonorrhoea nearly four times $(3 \cdot 9)$. The most common venereal disease was gonorrhoea ( 29 per cent. of the total cases in males and 21 per cent. in females). Numerically syphilis accounted for only $2 \cdot 6$ per cent. of male and 5.6 per cent. of female cases but the seriousness of this condition gives it an importance far greater than is implied by mere numbers. Soft sore accounted for only 0.3 per cent. of male infections and the cases of lymphogranuloma venereum and granuloma inguinale, even when combined, were too small for inclusion in Fig. 1.

In males, non-gonococcal urethritis accounted for a significant proportion ( $23 \cdot 5$ per cent.) with no comparable figures in females. "Other conditions" include cases of venereophobia, genital sores (due to herpes genitalis, molluscum contagiosum, scabies, genital warts, etc.) and in the female trichomoniasis and vaginal thrush.

It may well be that trichomoniasis is, in fact, the most common venereal disease but, without entering into controversy concerning its transmission, it has been excluded from consideration because there are no official figures to discuss. It is proposed to consider the various venereal diseases in ascending order of importance, although this paper is mainly concerned with syphilis and gonorrhoea.

\section{Granuloma Inguinale (Donovanosis)}

Even in countries where venereal diseases are rife, Donovanosis, which is of low infectivity, is relatively very uncommon. In the clinics of England and Wales, only thirteen male cases and three female cases were treated in 1960, although other women doubtless attended gynaecological departments. It is more common in West Indian immigrants. Eight males and four females were treated in 1959 compared with six males and one female in 1949. This slight increase could arise as much from a greater awareness of this condition as from a true increase in prevalence.

\section{Lymphogranuloma Venereum}

This disease caused 96 male and four female infections in 1960. As it is more prevalent in hot climates and in less developed populations, and has a longish incubation period, it might be anticipated that recent immigration trends could have caused it to be imported in some numbers from the West Indies, and to a lesser extent from West Africa and Pakistan.

Whether this is so, or whether the virus does not enjoy the vagaries of the English climate, is not very clear, but the figures, although increasing, have not risen very substantially in recent years. In 1959, 75 males and five females were treated, compared with 61 males and two females in 1954, and 58 males and one female in 1949.

\section{Soft Sore (Chancroid)}

Chancroid is common in conditions of poverty and poor hygiene. Where the incidence of syphilis is still very high (e.g. in parts of Africa) so is that of chancroid. In Africans in Southern Rhodesia, for example, it may be responsible for 20 per cent. of cases of penile sore (Willcox, 1951).

In the clinics of England and Wales in 1925 there were 1,048 male cases but only 27 female. The peak was reached in 1929 (1,202 males), and in 1941 there were 1,017 male cases, since which time there has been a steady fall, to only 265 males and only two females in 1959, and 226 males and five females in 1960.

A number of cases are probably not recorded. The use of sulphonamides (which do not affect $T$. pallidum but are curative for chancroid) in patients with genital sores undergoing dark-field tests for syphilis, and the improvement in washing facilities for the population as a whole, have doubtless contributed to this decline.

\section{Non-gonococcal Urethritis}

This presents a much more serious problem. The numbers of cases in males have been published only since 1951, but there has been a steady and significant rise ever since (Table II and Fig. 2), the incidence having increased by approximately 104 per cent. in 9 years, while gonorrhoea in males has increased by 77 per cent.

However, as the causative organism in the majority of cases has not yet been identified, and it is not therefore possible to identify the counterpart of the disease in the female with any accuracy, its epidemiology cannot profitably be discussed. Some cases may have been cases of gonorrhoea in which antibiotics or sulphonamides had previously been taken by the patient, but not declared, but the independent aetiology of the vast bulk of cases is not in dispute.

Some patients with non-gonococcal urethritis develop Reiter's syndrome-a chronic, relapsing, and sometimes crippling illness, which may have effects as serious as the late effects of syphilis. Whether all patients with non-gonococcal urethritis are potential candidates for Reiter's syndrome, or whether this is a separate disease, is not known. No 
TABLE II

NON-GONOCOCCAL URETHRITIS AND GONORRHOEA IN MALES, $1951-1960$

\begin{tabular}{c|c|c}
\hline Year & $\begin{array}{c}\text { Non-gonococcal } \\
\text { Urethritis }\end{array}$ & Gonorrhoea \\
\hline 1951 & 10,791 & 14,975 \\
1952 & 11,552 & 15,510 \\
1953 & 13,157 & 15,242 \\
1954 & 13,279 & 13,962 \\
1955 & 14,269 & 14,079 \\
1956 & 14,825 & 16,377 \\
1957 & 16,066 & 19,620 \\
1958 & 17,606 & 22,398 \\
1959 & 20,227 & 24,964 \\
1960 & 22,004 & 26,618 \\
\hline
\end{tabular}

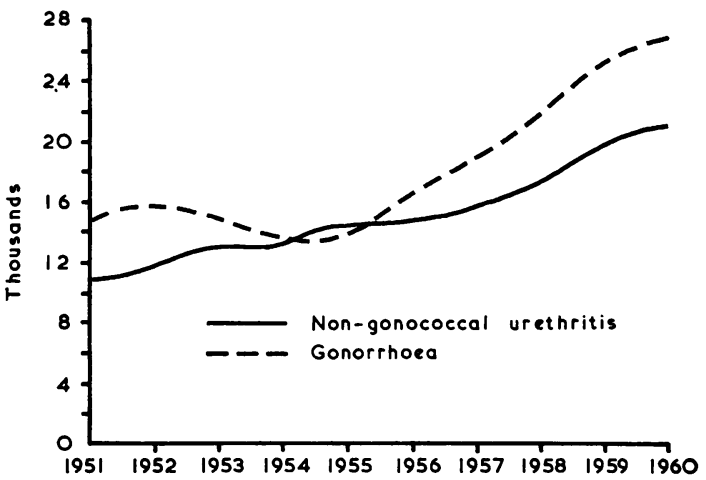

FIG. 2.-Incidence of non-gonococcal urethritis and gonorrhoea in males only, 1951-60.

records are available of the total number of cases of Reiter's syndrome, as many are nursed in medical and surgical wards and never seen in the venereal disease clinics.

\section{Syphilis}

The general situation is summarized in Table III and Fig. 3. The figures since 1925 show a gradual and steady decline for both sexes from 1925 to 1939 (when arsenical and bismuth therapy was still in use) and a return to pre-war levels between 1939 and 1945 , consequent upon the large numbers of new early cases occasioned by the war-time social upheaval. With the introduction of penicillin the decline was very much more striking. The 1960 figure for syphilis in males was only 20.4 per cent. of that for 1925 , and in females only 20.9 per cent.

Early Syphilis.-The cases of early syphilis (i.e. primary, secondary, and early latent syphilis of less
TABLE III

TOTAL INCIDENCE OF SYPHILIS, 1925-60 (Every third year)

\begin{tabular}{|c|c|c|c|c|}
\hline Year & Males & Females & Treatment Era & \\
\hline $\begin{array}{l}1925 \\
1927 \\
1930 \\
1933 \\
1936 \\
--\overline{1939}-\end{array}$ & $\begin{array}{r}11,782 \\
12,393 \\
11,967 \\
10,738 \\
8,224 \\
--\overline{7,273}-\end{array}$ & $\begin{array}{r}7,385 \\
7553 \\
6,916 \\
6,029 \\
5,128 \\
--\overline{4,605}-\end{array}$ & $\left\{\begin{array}{l}\text { Arsenic and Bismuth } \\
--------\end{array}\right.$ & \multirow{2}{*}{$\begin{array}{l}\text { Second } \\
\text { World } \\
\text { War }\end{array}$} \\
\hline $\begin{array}{c}1942 \\
1945 \\
---- \\
1948 \\
1951 \\
1954 \\
1957 \\
1960\end{array}$ & $\begin{array}{c}8,529 \\
8,134 \\
--7-- \\
9,780 \\
4,506 \\
2,969 \\
2,747 \\
2,401\end{array}$ & $\begin{array}{c}6,542 \\
8,508 \\
--7-- \\
7,349 \\
3,926 \\
2,352 \\
2,230 \\
1,545\end{array}$ & $\left\{\begin{array}{l}-------\ldots \\
\text { Penicillin }\end{array}\right.$ & \\
\hline
\end{tabular}

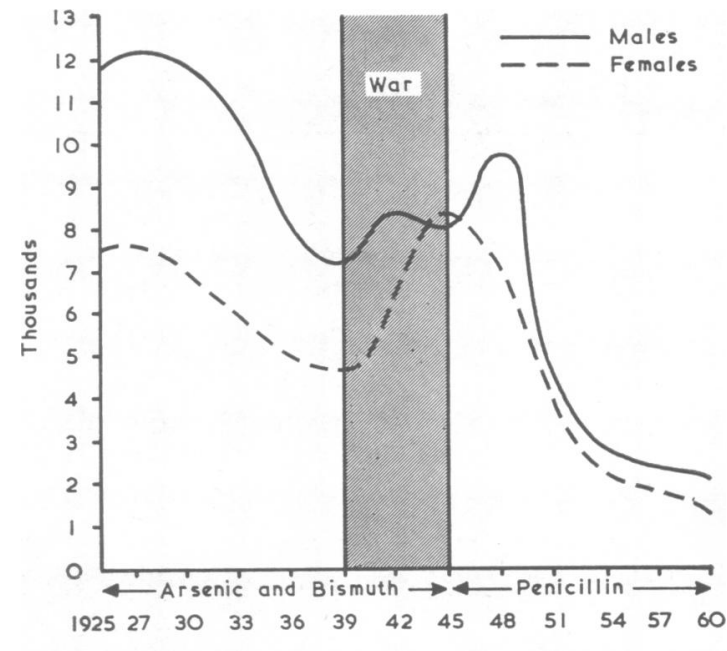

FIG. 3.-Total incidence of syphilis, by sex 1925-1960

than one year's duration), and also of congenital syphilis in different age groups, have been differentiated only since 1931 . The relative numbers of early infections permit an assessment of progress in dealing with the disease.

Males. - The reward of steady and continuous work by means of contact-tracing and treatment with arsenicals and bismuth (which had to be maintained in the individual patient for long periods) was a slow but significant drop in the numbers of early infections in males, from 6,421 cases in 1931 to 3,574 in 1939. The war undid this good work, and by 1942 the total had risen to 5,470 . The subsequent increase in male cases was concealed as so many were treated 
in the Services but, by 1946, as these men returned to civilian life (and many cases were transferred from service to civilian registers), the extent of this concealment became apparent and an all-time peak of 10,705 male cases was reached (Table IV and Fig. 4).

TABLE IV

CASES OF EARLY SYPHILIS TREATED IN THE CLINICS OF ENGLAND AND WALES, 1946-1960, BY SEX

\begin{tabular}{c|c|c}
\hline Year & Males & Females \\
\hline 1946 & 10,705 & 6,970 \\
1947 & 8,750 & 5,416 \\
1948 & 6,603 & 4,034 \\
1949 & 4,392 & 2,420 \\
1950 & 2,678 & 1,465 \\
1951 & 1,498 & 774 \\
1952 & 891 & 462 \\
1953 & 755 & 319 \\
1954 & 600 & 208 \\
1955 & 609 & 228 \\
1956 & 587 & 257 \\
1957 & 555 & 192 \\
1958 & 522 & 182 \\
1959 & 564 & 209 \\
1960 & 819 & 175 \\
& &
\end{tabular}

Females.-From 1931 to 1939 the numbers fell from 6,421 to 3,574 , and then rose steadily to a peak of 6,970 in 1946, when the situation was substantially worse than it had been 15 years before.

This state of affairs was transformed by the introduction during 1945-46 of penicillin, which rapidly rendered patients non-infectious, and provided a minimal curative treatment for close on 100 per cent. of cases, whereas formerly, owing to default and toxic effects, only approximately onequarter of patients could receive a proper dose of arsenicals and bismuth (Chope and Malcolm, 1948). The consequent drop in incidence was steep and dramatic (Table IV and Fig. 4); by 1958 there were only 522 male and 182 female cases - a mere 4.9 and 2.6 per cent. respectively of the 1946 peaks. During the next 2 years, however, there was a significant rise in male cases to over 800 in 1960 , and there is some evidence that this rise is continuing. The level for females after a slight rise in 1959 has begun to fall again.

Serious as this trend is, the prevalence of syphilis is still very low, the male cases in 1960 being only 7.7 per cent. and the female cases only 2.5 per cent. of the 1946 levels, but the same recent rise has been noted in other countries and its potential gravity should not be minimized.

The number of male cases is undoubtedly being increased by the activities of homosexuals, particularly in certain areas. At St. Mary's, Paddington, for example, of 155 male cases of early syphilis seen with my colleague Dr. Jefferiss in 1959-60, no less

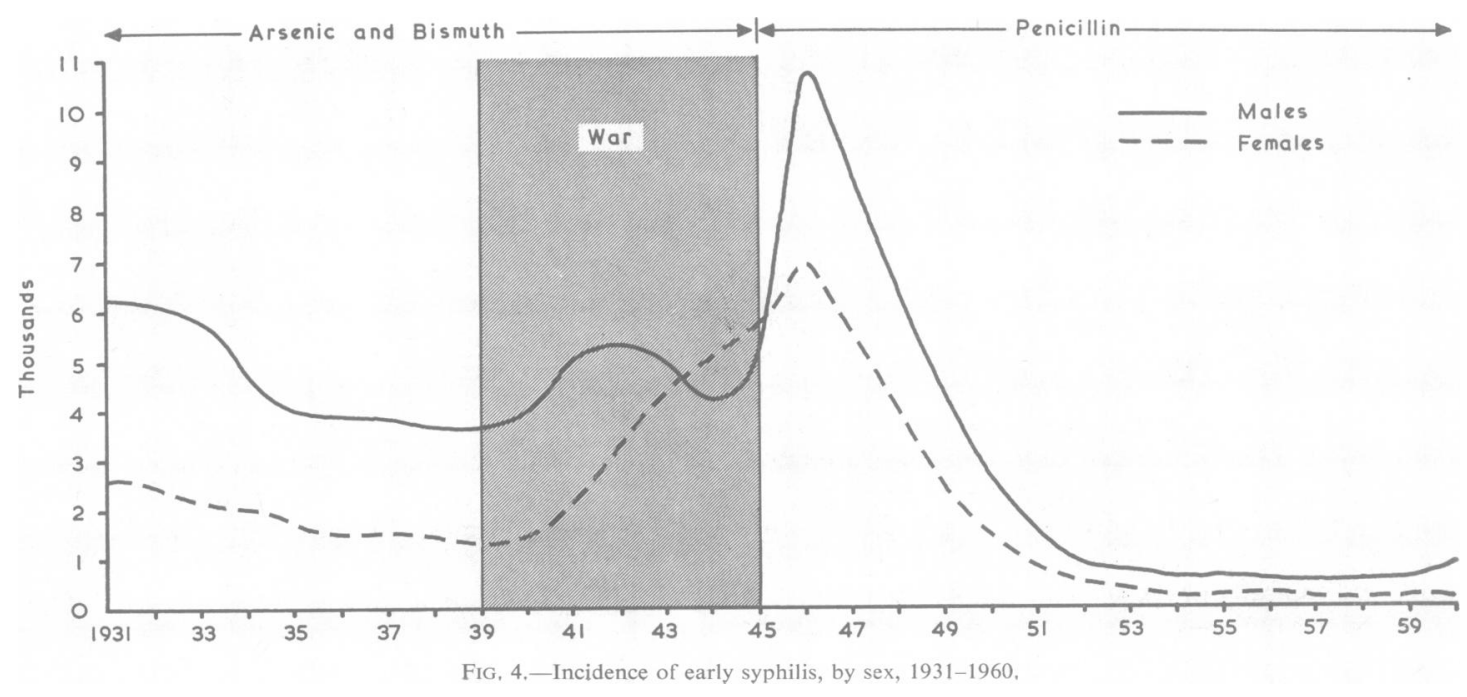


than 69 ( $44 \cdot 5$ per cent.) were homosexuals, who thus comprised nearly half the remaining male reservoir of infection.

Latent Syphilis.-The decline is indicated by the fall in positive results in routine serological tests of expectant mothers. The results from six regional centres as published by the Ministry of Health are shown in Table $\mathrm{V}$ and Fig. 5.

TABLE V

SERO-POSITIVITY RATES IN EXPECTANT MOTHERS, 1953-1959

\begin{tabular}{c|c|c|c|c}
\hline \multirow{2}{*}{ Year } & \multicolumn{2}{|c|}{ Primiparae } & \multicolumn{2}{c}{ Multiparae } \\
\cline { 2 - 4 } & $\begin{array}{c}\text { No. of } \\
\text { Cases }\end{array}$ & $\begin{array}{c}\text { Per cent. } \\
\text { Positive }\end{array}$ & $\begin{array}{c}\text { No. of } \\
\text { Cases }\end{array}$ & $\begin{array}{c}\text { Per cent. } \\
\text { Positive }\end{array}$ \\
\hline 1953 & 28,263 & $0 \cdot 21$ & 27,573 & 0.43 \\
1954 & 39,181 & $0 \cdot 23$ & 47,941 & $0 \cdot 32$ \\
1955 & 41,392 & 0.21 & 40,712 & 0.43 \\
1956 & 48,420 & 0.28 & 40,295 & 0.35 \\
1957 & 49,914 & 0.14 & 43,730 & 0.29 \\
1958 & 49,315 & $0 \cdot 13$ & 30,765 & $0 \cdot 23$ \\
1959 & 56,962 & 0.14 & 46,531 & 0.16 \\
\hline
\end{tabular}

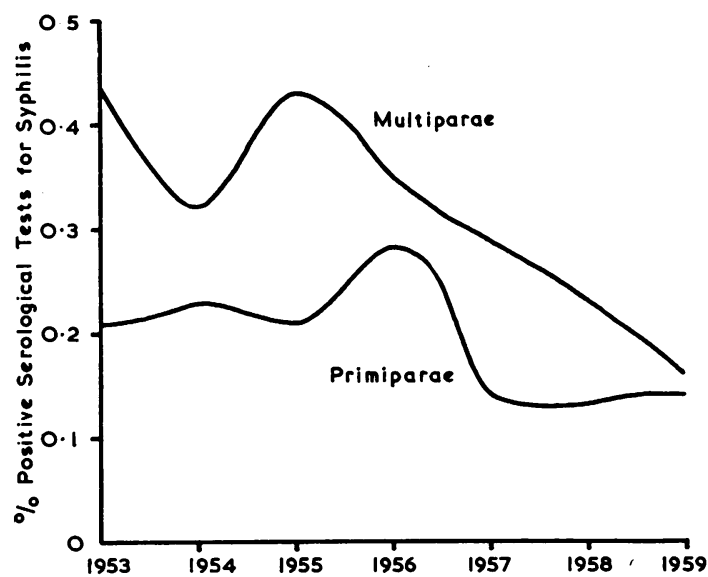

FIG. 5.-Percentage positive serological tests for syphilis in pregnant women, 1953-1959.

The rates have fallen between 1953 and 1959 from 0.21 to 0.14 per cent. in primiparae and from 0.43 to 0.16 per cent. in multiparae. These positive results do not necessarily indicate infectious cases of syphilis, as some may arise from false-positive reactions, from other treponematoses (e.g. yaws, which is being encountered much more frequently with the increasing numbers of female West Indian immigrants), from old congenital infections, or from known treated cases.
The present yield of only two positive results in approximately 3,000 tests is relatively low, and the expense is high in relation to the small numbers of potential infections revealed. However, especially in regard to the present uncertainty concerning early syphilis, it would be unwise to recommend their discontinuance while even one potentially syphilitic infant might escape detection.

Late Syphilis.-The figures may be calculated by subtracting the cases of early and congenital syphilis from the total, but because the published figures for congenital syphilis do not state the sex of the patient, it is only possible to present figures for both sexes combined. Table VI and Fig. 6 show a steady and continuous improvement, the 1959 figures being less than half those for 1931. The check in the fall during the war and in the immediate post-war period was probably due to the discovery of latent cases of unknown duration which were in fact relatively recent infections with no physical signs.

TABLE VI

LATE SYPHILIS, 1931-1960, MALE AND FEMALE TOGETHER

\begin{tabular}{c|c}
\hline Year & No. of Cases \\
\hline 1931 & 6,389 \\
1933 & 6,861 \\
1935 & 6,159 \\
1937 & 5,667 \\
1939 & 5,278 \\
1941 & 4,050 \\
1943 & 5,381 \\
1945 & 4,554 \\
1947 & 4,618 \\
1949 & 5,470 \\
1951 & 5,033 \\
1953 & 4,268 \\
1955 & 3,522 \\
1957 & 3,673 \\
1959 & 2,782 \\
1960 & 2,563 \\
\hline
\end{tabular}

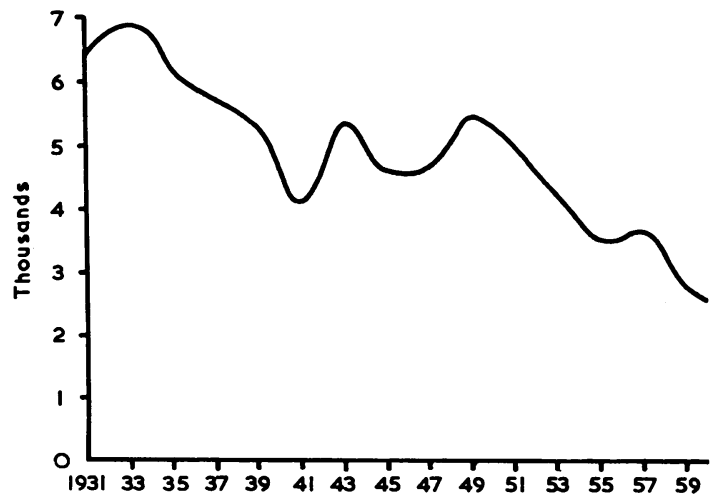

Fig. 6.-Total incidence of late syphilis, 1931-1960. 
The success of penicillin treatment is apparently affirmed and belies those pessimists who forecast an increase in late syphilis after early cases had been (perhaps inadequately) treated with the new drug.

The expected rise in late syphilis from "missed" cases of early syphilis in the war-time years has not yet appeared. This suggests that most of such cases have already been discovered through antenatal blood tests of the infected wives and the diagnosis of congenital syphilis in babies born during the years 1946-49. It must not be forgotten, however, that with the simplified treatments in use to-day more cases may be treated in other departments than was formerly the case.

There has also been a decline in the numbers of deaths from general paralysis of the insane, tabes dorsalis, and aortic aneurysm (Table VII and Fig. 7).

TABLE VII

DEATHS FROM SYPHILIS SINCE 1911

\begin{tabular}{c|c|c|c}
\hline Year & $\begin{array}{c}\text { General } \\
\text { Paralysis of } \\
\text { the Insane }\end{array}$ & $\begin{array}{c}\text { Tabes } \\
\text { Dorsalis }\end{array}$ & $\begin{array}{c}\text { Aneurysm of } \\
\text { the Aorta }\end{array}$ \\
\hline $1911-1920$ & 2,080 & 698 & 1,046 \\
$1921-1930$ & 1,481 & 758 & 1,109 \\
$1931-1935$ & 1,059 & 691 & 1,362 \\
$1936-1939$ & 852 & 577 & 1,548 \\
$1940-1944$ & 740 & 341 & 491 \\
$1945-1949$ & 268 & 198 & 511 \\
$1950-1954$ & 140 & 120 & 502 \\
1955 & 120 & 77 & 505 \\
1956 & 84 & 81 & 500 \\
1957 & 68 & 75 & 526 \\
1958 & 85 & 57 & 485 \\
1959 & 89 & 61 & 498 \\
1960 & 78 & & \\
\hline
\end{tabular}

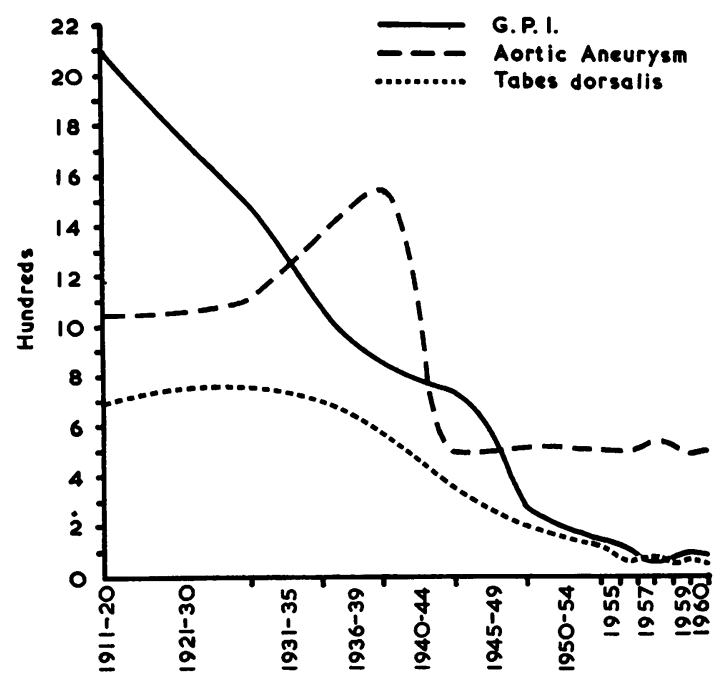

FIG. 7.-Deaths from syphilis, 1911-1960.
In all three conditions, however, during the last 5 , 6 , and 8 years, respectively, the levels have not substantially changed. This is probably due to the late results of previously undiagnosed war-time cases.

Congenital Syphilis.-There is no more striking example of the successful prevention of disease than that achieved in congenital syphilis. As with acquired syphilis, the numbers of cases in babies under one year old declined (Table VIII, and Fig. 8, opposite) from 339 in 1931 to 191 in 1940 , and the total number from 2,439 in 1931 to 1,358 in 1940 . These gains were lost during the war, and by 1946 the cases in babies under one year old had risen again to 363 . The war would not be expected immediately to influence the figures for those diagnosed at a later age, although it checked the fall in the numbers of both total and early cases in the immediate post-war years (Table VIII, and Fig. 8, opposite).

TABLE VIII

CONGENITAL SYPHILIS, 1931-1960

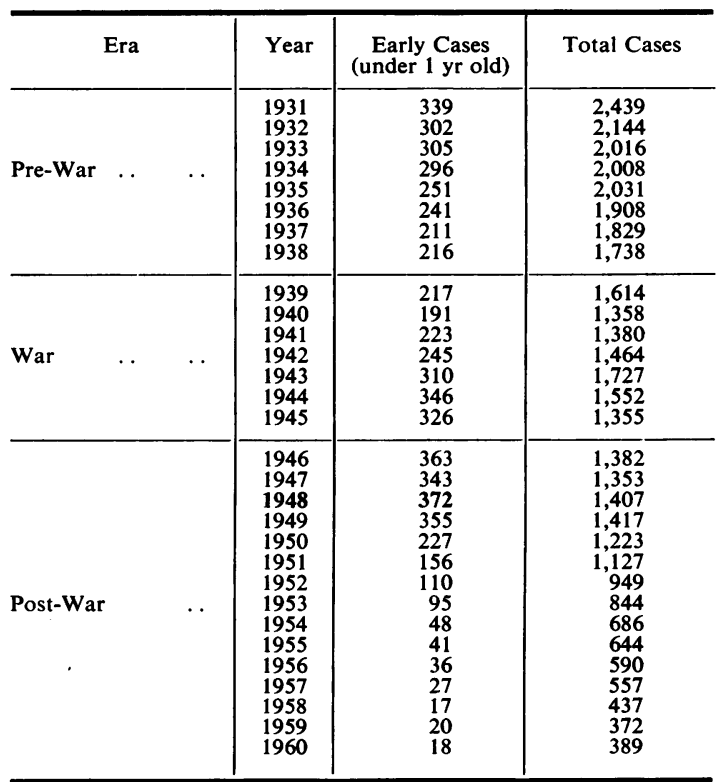

An all-time peak since 1931 of 372 cases of early infections was recorded in 1948 and there were 1,417 total infections in 1949. Doubtless many of the latter were the result of missed war-time infections disclosed by family contact-tracing following the birth of syphilitic children. The treatment of expectant mothers with penicillin has been, and still is, successful in preventing congenital syphilis in the child or in curing it in utero. Routine serological 

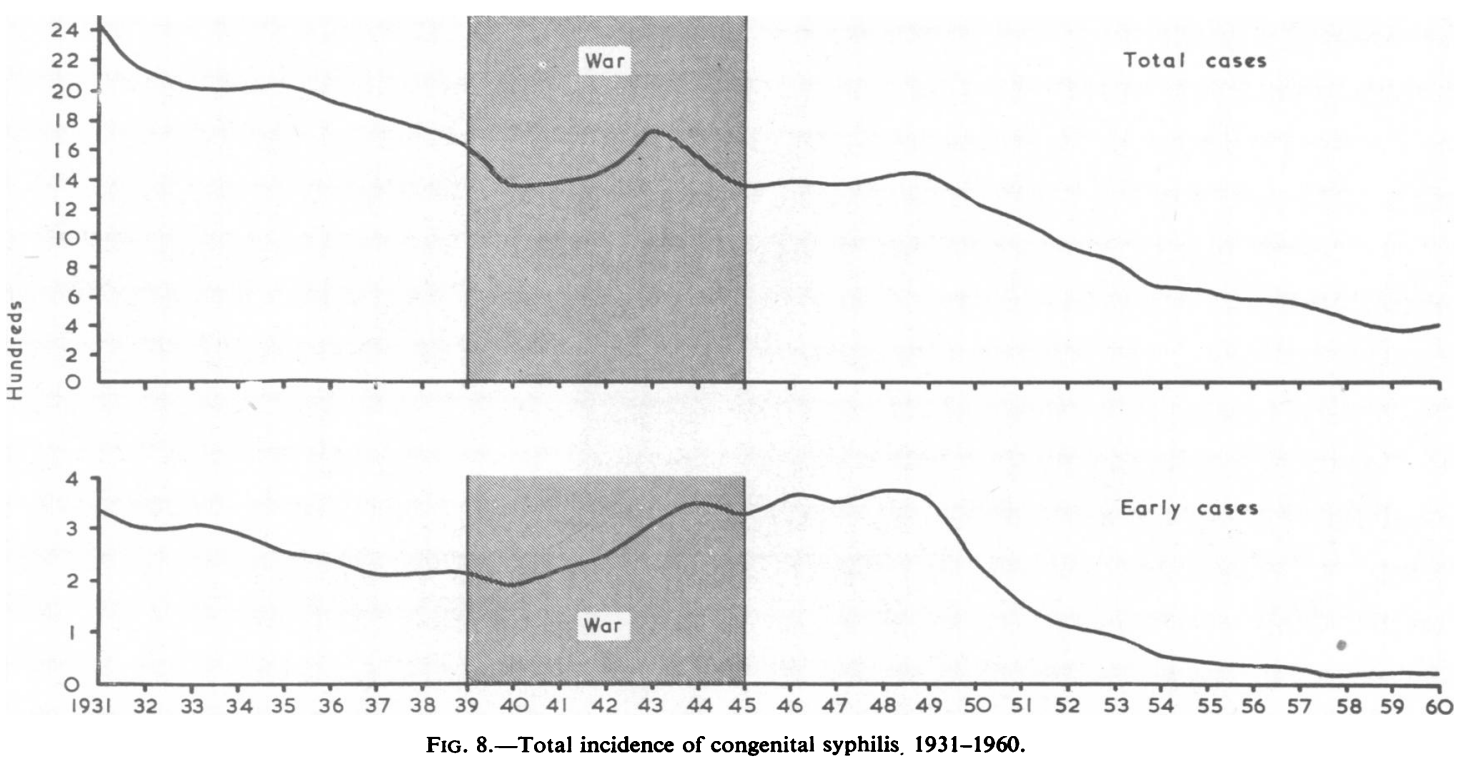

tests of pregnant women reveal the cases in which treatment should be given. This combined approach has brought down the total of early congenital syphilis in a spectacular fashion, so that in 1960 only eighteen babies under the age of one year were treated in the clinics of England and Wales ( $5 \cdot 3$ per cent. of the total for 1931).

\section{Gonorrhoea}

The figures for gonorrhoea can be considered in three phases.

Pre-sulphonamide Era (1925-1935).-Patients were treated mainly with irrigations and virtually had to kill their own gonococci, and no progress was made (Table IX).

In 1925 some 24,398 infections were treated in males, and the figure was even higher $(27,506)$ in 1935 , after a peak of 32,217 noted during the economic depression of 1930 (Fig. 9, overleaf).

In females 6,120 cases were treated in 1925 and 7,732 in 1935, after a peak of 8,583 in 1933 (Fig. 9). There was no evidence of control at this time.

Sulphonamide Era (1936-1944).--There was a striking fall in male cases from 28,137 in 1936 to 16,629 in 1944 , but this was more apparent than real,
TABLE IX INCIDENCE OF GONORRHOEA, BY SEX ACCORDING TO TREATMENT AVAILABLE

\begin{tabular}{|c|c|c|c|}
\hline Treatment Era & Year & Males & Females \\
\hline Pre-Sulphonamide & $\begin{array}{l}1925 \\
1926 \\
1927 \\
1928 \\
1929 \\
1930 \\
1931 \\
1932 \\
1933 \\
1934 \\
1935\end{array}$ & $\begin{array}{l}24,398 \\
25,535 \\
28,195 \\
30,425 \\
31,810 \\
32,217 \\
29,310 \\
28,179 \\
29,169 \\
28,787 \\
27,506\end{array}$ & $\begin{array}{l}6,120 \\
6,416 \\
6,809 \\
7,810 \\
7,798 \\
7,939 \\
7,697 \\
7,677 \\
8,583 \\
8,199 \\
7,732\end{array}$ \\
\hline Sulphonamide & $\begin{array}{l}1936 \\
1937 \\
1938 \\
1939 \\
1940 \\
1941 \\
1942 \\
1943 \\
1944\end{array}$ & $\begin{array}{l}28,137 \\
29,250 \\
27,947 \\
24,811 \\
21,057 \\
20,572 \\
17,936 \\
18,215 \\
16,629\end{array}$ & $\begin{array}{r}7,715 \\
7,787 \\
7,746 \\
6,489 \\
5,882 \\
7,314 \\
8,413 \\
10,043 \\
10,646\end{array}$ \\
\hline Penicillin .. & $\begin{array}{l}1945 \\
1946 \\
1947 \\
1948 \\
1949 \\
1950 \\
1951 \\
1952 \\
1953 \\
1954 \\
1955 \\
1956 \\
1957 \\
1958 \\
1959 \\
1960^{*}\end{array}$ & $\begin{array}{l}21,280 \\
36,912 \\
29,647 \\
25,006 \\
20,366 \\
17,007 \\
14,975 \\
15,510 \\
15,242 \\
13,962 \\
14,079 \\
16,377 \\
19,620 \\
22,398 \\
24,964 \\
26,618\end{array}$ & $\begin{array}{r}11,603 \\
10,431 \\
7,019 \\
5,306 \\
4,121 \\
3,497 \\
3,089 \\
3,585 \\
4,021 \\
3,574 \\
3,766 \\
4,011 \\
4,761 \\
5,489 \\
6,380 \\
7,152\end{array}$ \\
\hline
\end{tabular}

* Provisional from addition of quarterly returns. 


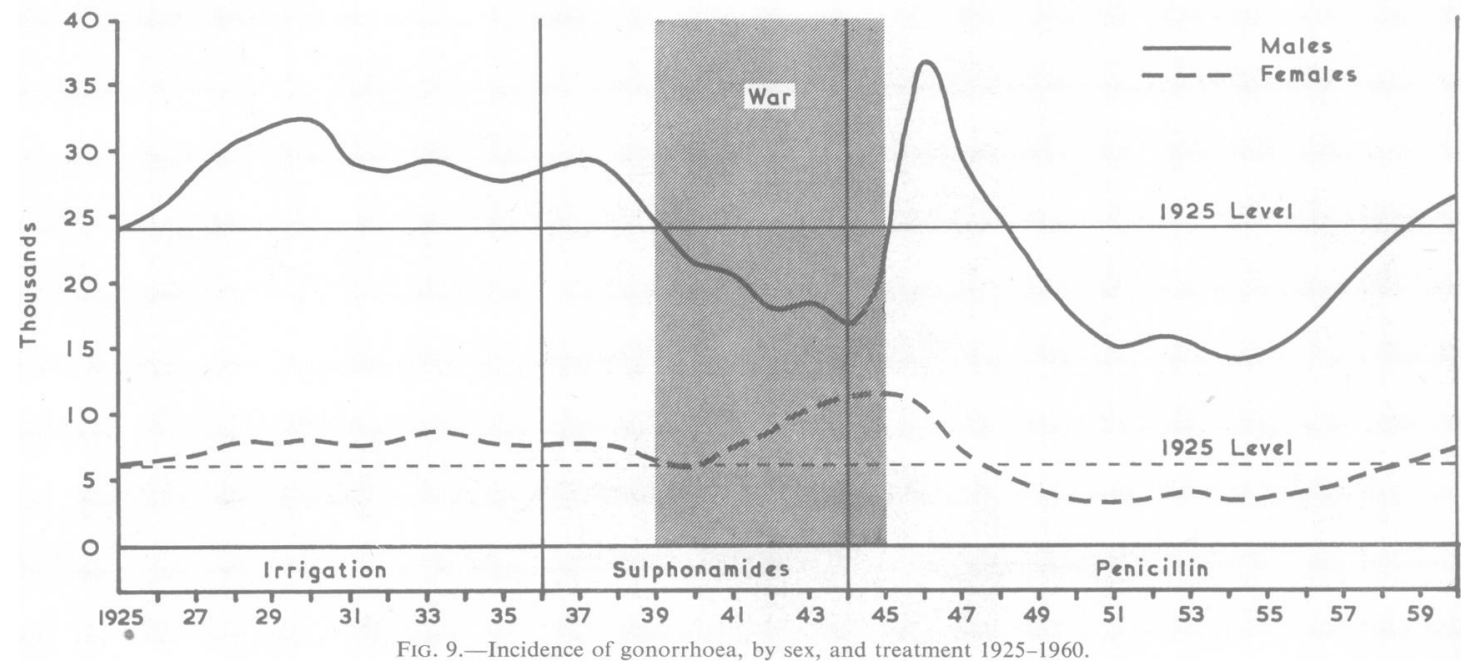

for more and more young men were being inducted into the Armed Forces and their numerous gonococcal infections did not appear in the civilian returns. This is very evident in the numbers of female cases, 7,715 in 1936 and 7,787 in 1937; with sulphonamides (and the added inconvenience of aerial bombardment) the total fell to 5,882 in 1940 , but subsequently not even the sulphonamides could compete with the situation created by war and in 1945 no less than 10,646 female cases were reported. At this time gonococcal resistance to sulphonamides was not a striking feature in Great Britain, although it was already being encountered in other areas, e.g. Italy (Campbell, 1944).

Penicillin Era (1945-60). - The war-time rise overspilled into the post-war years (Table IX), and the true situation in males became apparent as the men were discharged from the Services; in 1946 no less than 36,912 cases (an all-time peak since 1925) were reported (Fig. 9). The peak in females $(11,603)$ occurred in 1945 (Fig. 9).

Stabilization of sexual relationships brought about a quick fall, aided by penicillin which rapidly removed infections and coped more than adequately with the increasing numbers of cases which were resistant to the sulphonamides.

In 1951 there were only 14,975 male cases $(40 \cdot 6$ per cent. of the 1946 peak), and after a temporary check the total fell still further to 13,962 in 1954 (only 37.8 per cent. of the 1946 peak). Since this time, however, there has been a steady deterioration, with a steep unbroken rise in males to 26,618 cases in $1960(72 \cdot 1$ per cent. of the 1946 peak).

In 1951 there were only 3,809 female cases $(26 \cdot 6$ per cent. of the 1945 peak), but the total has since risen again to 7,152 in 1960 (61.6 per cent. of the 1945 peak).

The 1960 totals for both sexes now exceed those of 1925 , and thus indicate an overall failure to control the disease (Fig. 9). Moreover, since penicillin was brought into use, a number of other antibiotics have been introduced which are effective in gonorrhoea. Any gain achieved by the introduction of new and effective treatments has thus proved only temporary, and this is a world-wide phenomenon. There is, however, some evidence that the rate of increase of gonorrhoea is now decreasing (Fig. 10, opposite).

\section{Reasons for the Difference in Incidence Between Syphilis and Gonorrhoea}

The essential points are summarized in Table $\mathrm{X}$ (opposite: see Guthe, 1958; Brown, 1961; Willcox, 1961).

Gonorrhoea is more common than syphilis and is easier to acquire from a single exposure. Moreover, no-one is immune to gonorrhoea, although some (e.g. sero-reactors) may be at least partially immune to syphilis. The shorter incubation period of gonorrhoea ( 2 to 5 days) than of syphilis (17 to 28 days) offers several significant advantages in favour of the control of syphilis. It is theoretically possible for 512 cases of gonorrhoea to develop for only one new case of syphilis, and by the time there are four cases of syphilis the whole world could be infected 


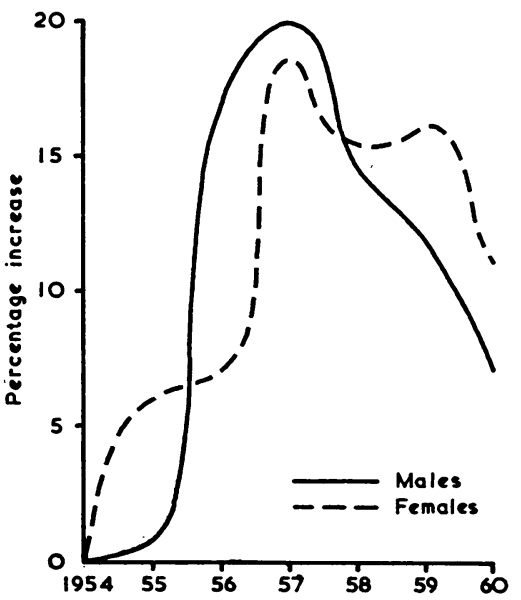

Fig. 10.-Percentage increase of gonorrhoea on previous year, by sex, 1954-1960.

TABLE X

REASONS FOR DIFFERENCE IN INCIDENCE BETWEEN SYPHILIS AND GONORRHOEA

\begin{tabular}{|c|c|}
\hline Gonorrhoea & Syphilis \\
\hline $\begin{array}{l}\text { More common } \\
\text { Easier to acquire }\end{array}$ & $\begin{array}{l}\text { Less common } \\
\text { Less easy to acquire from a } \\
\text { single exposure }\end{array}$ \\
\hline No persons immune & Some persons immune \\
\hline $\begin{array}{l}\text { Short incubation period } \\
\text { ( } 2-5 \text { days): therefore: } \\
\text { (1) Contact-tracing less ef- } \\
\text { fective } \\
\text { (2) Less easy to abort in incu- } \\
\text { bation period by penicillin } \\
\text { given for other purposes } \\
\text { (3) Appears first, and is not } \\
\text { aborted by treatment for } \\
\text { syphilis acquired at same } \\
\text { exposure }\end{array}$ & $\begin{array}{l}\text { Long incubation period } \\
\text { (17-28 days): therefore: } \\
\text { (1) Contact-tracing more ef- } \\
\text { fective } \\
\text { (2) Several times more likely } \\
\text { than gonorrhoea to be } \\
\text { aborted in incubation } \\
\text { period by penicillin given } \\
\text { for other reasons } \\
\text { (3) Appears second, and will } \\
\text { probably be aborted by } \\
\text { treatment for gonorrhoea } \\
\text { acquired at same exposure }\end{array}$ \\
\hline $\begin{array}{l}\text { No screening tests for latent } \\
\text { cases }\end{array}$ & $\begin{array}{l}\text { Routine serum tests lead to } \\
\text { diagnosis }\end{array}$ \\
\hline $\begin{array}{l}\text { Treatment somewhat less ef- } \\
\text { fective than formerly }\end{array}$ & $\begin{array}{l}\text { No deterioration in treatment } \\
\text { results }\end{array}$ \\
\hline $\begin{array}{l}\text { Disease often taken less } \\
\text { seriouslybypatient and } \\
\text { physician }\end{array}$ & $\begin{array}{l}\text { Disease taken more seriously } \\
\text { as late effects are better } \\
\text { known and feared }\end{array}$ \\
\hline
\end{tabular}

with gonorrhoea! (Table XI). With a few exceptions (for syphilis can be infectious even in the incubation period), there is more time during which the contacts of a syphilitic patient can be traced, so that "ping-pong" re-infections of the original subject and further spread to the community can be prevented. In gonorrhoea, on the other hand, with the short incubation period, the contact-tracer is frequently one lap behind, and by the time the source of infection is traced-albeit after only a few daysthe disease has already been spread yet further. As
TABLE XI

THEORETICAL POSSIBLE RATES OF MULTIPLICATION OS SYPHILIS AND GONORRHOEA

\begin{tabular}{c|c|c}
\hline \multirow{2}{*}{ No. of Days } & \multicolumn{2}{|c}{ No. of Cases Infected } \\
\cline { 2 - 3 } & Syphilis & Gonorrhoea \\
\hline 20 & 1 & 512 \\
\hline 40 & 2 & 524,288 \\
\hline 60 & 4 & $536,870,912$ \\
\hline
\end{tabular}

syphilis is the more serious disease, contact-tracing also tends to be taken more seriously. Also, because the incubation period is longer, penicillin given for other reasons (e.g. bronchitis, sore throat, boils, etc.) is, theoretically, case for case, very much more likely to abort syphilis in unsuspecting persons who may be incubating the disease. This is particularly true of patients already being treated for venereal disease. Penicillin given for the gonorrhoea, which appears first, will in most cases abort the simultaneously-acquired syphilis, whereas the reverse can seldom operate. The influence of this factor depends on the syphilis/gonorrhoea ratio. In the U.K. it operated in favour of syphilis only until 1951 (Figs 11 and 12 , overleaf).

Moreover, there are no screening tests to reveal latent cases of gonorrhoea, whereas routine serum tests for syphilis are performed for a variety of reasons, and in some cases a positive result may bring even very early infectious cases to treatment. Although syphilis may remain infectious for longer than gonorrhoea without declaring itself, virtually latent gonorrhoeal infections are common in females and in male homosexuals.

The treatment of gonorrhoea with antibiotics is somewhat less effective than formerly because of a lessened sensitivity of some strains of gonococci, particularly to penicillin and streptomycin. Failure rates are higher and any failures that occur in female defaulters may lead to further spread of infection.

Gonorrhoea, which is so simply treated, is taken less seriously than syphilis and default rates without proper surveillance are high. With syphilis, on the other hand, there are as yet no signs of developing resistance of the treponeme to penicillin (Turner and Hollander, 1957), and there has been no deterioration in the results of therapy.

\section{Summary}

(1) Trends in the prevalence of the various venereal diseases, based on a consideration of the published figures, are desçribed. 


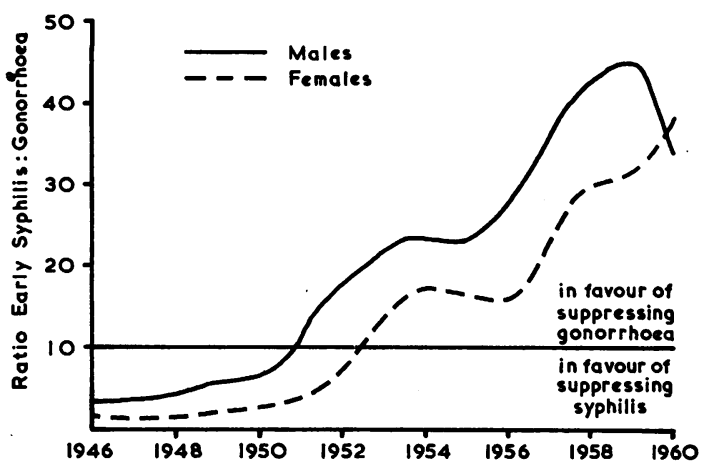

FIG. 11.-Effect of use of penicillin during incubation period on ratio of early syphilis cases to gonorrhoea cases, by sex, 1946-1960.

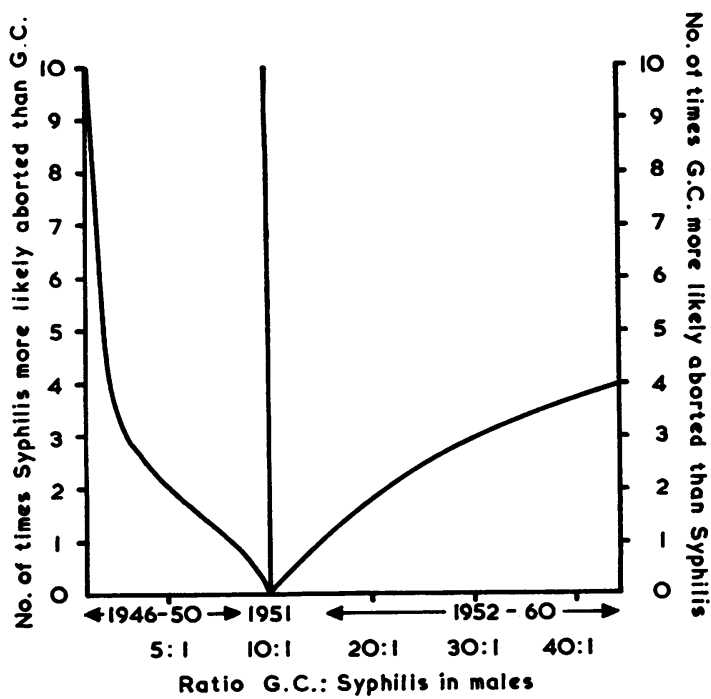

FIG. 12.-Effect of use of penicillin during incubation period on ratio of early syphilis cases to gonorrhoea cases, in males only, 19461960.

(2) Soft sore, lymphogranuloma venereum, and granuloma inguinale offer relatively insignificant problems. Non-gonococcal urethritis in males, however, has shewn a 104 per cent. increase during the decade for which figures are available.

(3) The numbers of cases of early syphilis in both sexes showed a slow and steady decline under the influence of contact-tracing and treatment with arsenicals and bismuth. This limited success was undone by World War II, and by 1946 all-time peak figures were reported in both sexes. The impact of penicillin therapy caused a sharp fall, and by 1958 the numbers treated represented only 4.9 and 2.6 per cent. of the 1946 figures in males and females respectively. Since 1958 there has been a small but significant resurgence, and the 1960 figures represented 7.7 and $2 \cdot 5$ per cent. of the 1946 figures. A large proportion of the residue in males exists in homosexuals.

(4) Latent syphilis, judged by sero-positivity discovered by routine tests of expectant mothers, late syphilis, judged by the figures published by the Ministry of Health, and deaths from neurosyphilis and aortic aneurysm, all shew a continuing downward trend. This can only reaffirm the faith which has been placed in penicillin therapy. No increase has yet been encountered as a result of cases missed in the earlier peak years.

(5) The fall in the numbers of cases of early congenital syphilis (to 5.9 per cent. in 1960 of the 1931 figures) is one of the great triumphs of modern preventive medicine, and has been achieved by the combined use of antenatal blood tests and the rapid treatment with penicillin of syphilitic expectant mothers.

(6) The situation as regards gonorrhoea gives no grounds for complacency; it is in fact alarming.

In the pre-sulphonamide era (1925-1935) no progress was made and more cases were being treated in the clinics at the end than at the beginning.

The sulphonamide era (1936-45) showed some? improvement, but this was upset by the war (and the developing resistance of the gonococcus to sulphonamide drugs). By 1945-46, all-time peak figures were reported in both sexes.

The penicillin era, which began about 1945, brought a striking fall in numbers of cases although this was less striking than the fall in cases of syphilis. By 1951 , the female cases were only $26 \cdot 6$ per cent. of the 1946 peak figures and the male cases were 40.6 per cent. The latter had fallen still further to 37.8 per cent. by 1954 . Since this time there has been a serious deterioration, and in 1960 more cases were treated than in 1925, indicating an overall failure to control the disease.

(7) The difference between the figures for syphilis and those for gonorrhoea are discussed. The chief reasons are that gonorrhoea is more infectious after a single exposure, has a much shorter incubation period, and is less likely to be aborted by penicillin given for other complaints.

(8) The reasons for the failure to control gonorrhoea are discussed elsewhere (Willcox, 1962). 


\section{REFERENCES}

British Cooperative Clinical Group (1956). Brit. J. vener. Dis., 32, 21 . (1959). Ibid., 35, 111. (1960a). Ibid., 36, 216. (1960b). Ibid., 36, 233. (1962). Ibid., 38, 1 .

Brown, W. J. (1961). Bull. Wld Hlth Org., 24, 386.

Campbell, D. J. (1944). Brit. med. J., $2,44$.

Chope, H. D., and Malcolm, J. C. (1948). J. vener. Dis. Inform., 29, 173.

Guthe, T. (1958). Bull. Wld Hlth Org., 19, 405.

Leviticus, $x v, 2-12$, and $x x i i, 4$.

Ministry of Health (1961). "Report of the Ministry of Health for the year 1960. Pt II. On the State of the Public Health", Appendix C, p. 225. Cmnd 1550. H.M.S.O., London. See Brit. J. vener. Dis. (1962), $38,43$.

NUMBERS, $x x x i, 17$.

Turner, T. B., and Hollander, D. H. (1957). "Biology of the Treponematoses", W.H.O. Monograph Series No. 35. W.H.O., Geneva.

Willcox, R. R. (1949). Brit.J. vener. Dis., 25, 28.

(1951). Bull. Wld Hlth Org., 4, 283.

(1961). Ibid., 24, 357.

_ (1962). Brit. J. prev. soc. Med., 16, 113.

Développement de l'incidence des maladies vénériennes en Angleterre et au Pays de Galles

RÉSUMÉ

(1) L'auteur décrit le développement de l'incidence des maladies vénériennes indiqué par la statistique officielle.

(2) Les problèmes du chancre mou, du lymphogranulome vénérien, et du granulome inguinal ont peu d'importance. Cependant, les cas d'urétrite nongonococcique chez le mâle ont augmenté de $104 \%$ pendant les 10 ans pour lesquels les statistiques démographiques ont été publiées.

(3) Le taux des cas de syphilis précoce parmi les deux sexes a diminué lentement mais régulièrement grâce à la recherche des consorts sexuels et au traitement par l'arsenic et le bismuth. Ce succès limité fut défait par la deuxième guerre mondiale et les chiffres atteignirent un sommet inoui en 1946.

Une chute dramatique suivit la découverte de la pénicilline, telle que les cas traités en 1958 n'étaient que $4,9 \%$ (pour les hommes) et $2,6 \%$ (pour les femmes) de ceux traités en 1946 .

Depuis 1958 il y a en une recrudescence faible mais significative, telle que les cas traités en 1960 représentérent $7,7 \%$ (pour les hommes) et $2,5 \%$ (pour les femmes) de ceux traités en 1946.

Parmi les hommes une grande partie de cette augmentation est due aux homosexuels.

(4) La syphilis latente (découverte par les tests sérologiques des femmes enceintes) et la syphilis tardive (à suivre les statistiques du Ministère de la Santé et les décès certifiés comme dus à la neurosyphilis et à l'anévrisme aortique) continuent à diminuer, ce qui confirme la valeur de la pénicilline. Ou n'a pas encore rencontré une augmentation due aux cas non-dépistés quand l'incidence de la syphilis précoce était si élevée.

(5) La diminution du nombre de cas de syphilis congénitale précoce $(5,9 \%$ en 1960 du nombre de 1931$)$ est une des grandes victoires de la médecine préventive, et est due à la surveillance prénatale et au traitement rapide des femmes enceintes.

(6) La recrudescence de la gonorrhée est dangereuse. Avant l'introduction des sulfonamides (1925-36) aucun progrès ne fut fait et il y avait plus de cas à la fin de cette époque qu'au commencement. Les sulfonamides amenèrent une amélioration, mais celle-ci fut enrayée par la guerre (et aussi par la résistance de quelques souches à ces médicaments). En 1945-46 les chiffres pour les deux sexes furent plus élévés que jamais.

L'époque de la pénicilline qui commença en 1945-46 vit une chute remarquable (mais pas si étonnante que celle de la syphilis). En 1951 le taux des femmes atteintes représentait $26,6 \%$ du niveau de 1946 et celui des hommes $40,6 \%$. Il tomba ensuite jusqu'à $37,8 \%$ en 1954 . Cependant depuis 1954 il y a en une grave détérioration; en 1960 plus de malades furent traités qu'en 1925-indication d'un échec général du contrôle de la maladie.

(7) L'auteur discute les différences entre les statistiques pour la syphilis et la gonorrhée. Ces différences sont surtout dues au fait que la blennorragie est plus infectieuse; un seul contact suffit et la période d'incubation est très courte.

(8) Les causes de l'échec du contrôle de la blennorragie sont décrites ailleurs. 